\title{
Phylogeny and biogeography of Triportheidae (Teleostei: Characiformes) based on
}

molecular data

T.C. Mariguela $a^{a^{*}}$, F.F. Roxo ${ }^{b}$, F. Foresti ${ }^{b}$, C. Oliveira ${ }^{b}$

aDepartamento de Zoologia, Instituto de Biociências, Univ. Estadual Paulista - UNESP, Rio Claro, São Paulo, Brazil.

${ }^{b}$ Departamento de Morfologia, Instituto de Biociências, Univ. Estadual Paulista UNESP, Botucatu, São Paulo, Brazil.

*Corresponding author: Tel: +551935269624 E-mail address: tatimariguela@gmail.com (Tatiane C. Mariguela). Departamento de Zoologia, Instituto de Biociências, UNESP - Univ. Estadual Paulista, Zipcode: 13506-900, Rio Claro, São Paulo, Brazil.

Keywords: Evolution, Freshwater sardines, Phylogeny, Molecular Systematics, Neotropical fishes. 


\begin{abstract}
Triportheidae represents a relatively small family of characiform fishes with highly modified morphology. The relationship among characiform families is still unclear, and a phylogenetic analysis for the family including a representative number of Triportheus species has never been performed. Here, we inferred a phylogeny for 19 of the 22 species recognized for this family and two possible new Triportheus species using two mitochondrial and three nuclear genes. Our results show that (1) Triportheidae is monophyletic and a sister group of the clade consisting of the families Bryconidae and Gasteropelecidae; (2) Triportheus is monophyletic, but some species need to be reviewed and described; (3) all genera in Triportheidae, except for Agoniates originated in the period between Early Oligocene and Early Miocene; and (4) speciation in Triportheidae coincides with important geological events in South America, reinforcing the importance of time-calibrated trees to study fish evolution.
\end{abstract}




\section{Introduction}

The order Characiformes contains about 2,091 species distributed among 19 exclusively Neotropical families and four exclusively African families (Arroyave and Stiassny, 2011; Oliveira et al., 2011; Eschmeyer and Fong, 2015). Many taxonomic studies of this order have been performed, with the description of 309 species (approximately $15 \%$ of the total number of species) in the last 10 years (Eschmeyer and Fong, 2015). Oliveira et al. (2011) recognized Triportheidae as a valid characiform family and included in it the genera Agoniates (two species), Clupeacharax (one species), Engraulisoma (one species), Lignobrycon (one recent species) and Triportheus (17 species).

Malabarba (1998) found eight synapomorphies supporting a close relationship between Triportheus and Lignobrycon, but until now no additional morphological studies involving the remaining genera were published. Although this is a small group of characiforms, it contains highly modified species and its phylogenetic position among Characiformes remains unclear. Previous molecular studies suggested that Triportheidae could be the sister group of Gasteropelecidae or Bryconidae (Fig. 1), but in all of these studies, only a few specimens of Triportheus, the largest Triportheidae genus, were analyzed.

\section{FIGURE 1}

Considering the lack of information about the phylogenetic position of the Triportheidae among the Characiformes, two mitochondrial and three nuclear genes were sequenced for 19 of the 22 species currently recognized for this family and for representatives of all other Characiformes families. Therefore, the main goal of the 
present study was to formulate a hypothesis of the relationships among the Triportheidae species and genera and between this family and the other characiform families. In addition, a time-calibrated tree was inferred to investigate the temporal relationships between the origin of the Triportheidae species and genera and the main geological events in South America such as the formation of Magdalena, Amazonas, Paraguay, and São Francisco River basins.

\section{Materials and methods}

\subsection{Taxa sampling and delineation of the ingroup and outgroup}

The ingroup was composed of 32 specimens including representatives of 19 of 22 recognized Triportheidae species and two putative new, here identified as Triportheus aff. rotundatus and Triportheus sp. (Table 1). To test the position of Triportheidae in the Characiformes evolutionary tree, we used as outgroup the species employed by Oliveira et al. (2011) in their broad study of Characidae relationships with additional data from Gasteropelecidae (Abe et al., 2013) and Bryconidae (Abe et al., 2014). All specimens for this study were collected in accordance with Brazilian laws under a permanent scientific collection license in the name of Dr. Claudio Oliveira (IBAMA-SISBIO, 13843-1). Additionally, this survey was carried out in strict accordance with the recommendations for the National Council for the Control of Animal Experimentation and the Federal Board of Veterinary Medicine. The studied material was deposited in the Laboratório de Biologia e Genética de Peixes (LBP), Instituto de Biociências, Universidade Estadual Paulista, Botucatu, São Paulo, Brazil.

\section{TABLE 1}




\subsection{Molecular data collection}

Total DNA was extracted from ethanol-preserved muscle samples using the DNeasy Tissue Extraction Kit (Qiagen) following the manufacturer's instructions. Partial sequences of the mitochondrial genes 16SrRNA and Cytochrome $b(\mathrm{CytB})$ and the nuclear genes recombination activating gene 1 (Rag1), recombination activating gene 2 (Rag2) and myosin heavy chain 6 cardiac muscle alpha (Myh6) were amplified by polymerase chain reaction (PCR) with the primers listed in the Supplementary Material 1. Amplifications were performed in a total volume of $25 \mu$ consisting of 2.5 $\mu l$ 10X buffer (10 mM Tris-HCL, $15 \mathrm{mM} \mathrm{MgCl}$ ), $0.5 \mu \mathrm{MgCl}_{2}(50 \mathrm{mM}), 0.5 \mu \mathrm{l}$ each primer $(5 \mu \mathrm{M}) ; 0.4 \mu \mathrm{l}$ of dNTPs (200 nM of each), $0.2 \mu \mathrm{l} \mathrm{Taq} \mathrm{Platinum} \mathrm{polymerase}$

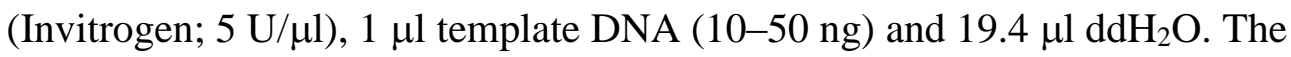
thermocycler profile used for the fragments 16SrRNA and CytB consisted of 35 cycles of $30 \mathrm{~s}$ at $95^{\circ} \mathrm{C}, 45-120 \mathrm{~s}$ at $50-55^{\circ} \mathrm{C}$, and $90 \mathrm{~s}$ at $72^{\circ} \mathrm{C}$. Nested PCR was used to amplify the nuclear genes Rag1, Rag2 and Myh6. Amplification conditions for these genes in both rounds of PCR consisted of 15 cycles of $30 \mathrm{~s}$ at $95^{\circ} \mathrm{C}, 45 \mathrm{~s}$ at $56^{\circ} \mathrm{C}$ (according to primer), and $30 \mathrm{~s}$ at $72^{\circ} \mathrm{C}$ followed by 15 cycles of $30 \mathrm{~s}$ at $95^{\circ} \mathrm{C}, 45 \mathrm{~s}$ at $54^{\circ} \mathrm{C}$ (according to primer), and $90 \mathrm{~s}$ at $72^{\circ} \mathrm{C}$. PCR products were purified using ExoSap-IT® (USB Corporation), sequenced using the Big DyeTM Terminator v 3.1 Cycle Sequencing Ready Reaction Kit (Applied Biosystems), purified again by ethanol precipitation and loaded into an automatic sequencer 3130 Genetic Analyzer (Applied Biosystems) at Instituto de Biociências, Universidade Estadual Paulista, Botucatu, São Paulo, Brazil. Contigs were assembled and edited in BioEdit 7.0.9.0 (Hall, 1999). In cases of unclear nucleotide identity, IUPAC ambiguity codes were applied. All obtained sequences were deposited in GenBank (Table 1). 


\subsection{Alignment and phylogenetic analyses}

Sequences of each gene were aligned using the MUSCLE algorithm under default parameters (Edgar, 2004), and the alignments were inspected by eye for any obvious misalignments that were subsequently corrected. A quality control step was included in our workflow as described in Oliveira et al. (2011). Genetic distances among sequences were calculated in Mega 5.04 (Tamura et al., 2011). To evaluate the occurrence of substitution saturation, we estimated the index of substitution saturation (Iss) in DAMBE 5.2.31 (Xia and Xie, 2001) as described in Xia et al. (2003) and Xia and Lemey (2009).

A set of six reasonable partitioning schemes ranging from 1 to 13 partitions was tested following the procedures outlined by Li et al. (2008) using the AICc (Akaike Information Criterion, corrected for finite sample sizes). The best-fit model of nucleotide substitution was searched in Mega 5.04 (Tamura et al., 2011) under default parameters using the AICc (see Posada and Buckley, 2004, for justification).

RAxML (Stamatakis, 2006) running in the web servers RAxML-HPC2 on TG (Stamatakis et al., 2008; Miller et al., 2010) was used for all maximum likelihood analyses with a mixed partition model. Random starting trees were run for each independent ML tree search, and all other parameters were set to default values. All ML analyses were conducted following the 13 partition scheme as suggested by the AICc. Topological robustness was investigated using 1,000 non-parametric bootstrap replicates.

The estimation of divergence times in the ML phylogeny was carried out using BEAST (Bayesian evolutionary analysis sampling trees) 1.8.0 (Drummond et al., 2012) on a reduced dataset that included the family Triportheidae and representatives of the families Gasteropelecidae, Bryconidae and Characidae. To calibrate our molecular 
clock, we followed the guideline proposed by Parham et al. (2012). The fossil species Lignobrycon ligniticus (Woodward, 1898) (type specimen: BMNH P9012) was studied by Malabarba (1998), who showed that L. ligniticus is the sister group of L. myersi (a species included in our phylogeny) and that these two species are the sister group of Triportheus.

Lignobrycon ligniticus was described based on complete specimens collected in the Tremembé Formation, Taubaté Basin, São Paulo, Brazil. Geological studies (Riccomini et al., 1991) confirmed the age of this formation as Oligocene, as also suggested by studies in mammalian fossils (Soria and Alvarenga, 1989) and pollens (Lima et al., 1985). According to the International Commission on Stratigraphy (www.stratigraphy.org), the Oligocene extended from 33.90 to 23.03 million years ago (Myr). These dates were implemented in BEAST v.1.8.0 (Drummond et al., 2012) with a log-normal prior offset of 28.5 and standard deviation of 1.8. We used a lognormal relaxed clock (uncorrelated) model and a birth-death process to calibrates our phylogenetic tree. Furthermore, we used the GTR (Generalized time-reversible, Tavaré 1986) for nucleotide substitution model. All clade-age estimates are presented as the mean and 95\% highest posterior density (HPD) values. The analysis was run for 20 million generations and sampled every $1,000^{\text {th }}$ generation. The tree obtained from RAxML analysis was used as an initial tree for the Bayesian inference. Stationarity and sufficient mixing of parameters (ESS > 200) were checked using Tracer 1.5 (Rambaut and Drummond, 2007a). All sampled topologies beneath the asymptote $(5,000,000$ generations) were discarded as part of a burn-in procedure. The remaining trees were used to built a 50\% majority-rule consensus tree using TreeAnnotator v.1.8.0 (Rambaut and Drummond, 2007b). 


\subsection{Estimation of ancestral ranges}

Data on the geographic distributions of species in the Triportheidae were taken from the original species descriptions and information available from the online Catalog of Fishes (Eschmeyer and Fong, 2015). To maintain consistency with previous biogeographic analyses of the family Characiformes we assigned taxa to geographic areas with modifications of ecoregion classifications of Vari (1988) and Vari and Malabarba (1998), which were defined by patterns of endemism in the Neotropical fishes. Our samples were drawn from the following eight ecoregions: (Region A) East Coastal Drainages, (Region B) Tocantins and Araguaia Basins, (Region C) São Francisco Basin, (Region D) Paraguay and Lower Paraná Basins, (Region E) Amazon Basin, (Region F) Orinoco and North Coastal Drainages, (Region G) Magdalena Basin, and (Region H) Parnaíba Basin.

We estimated likelihoods of ancestral range evolution using the DispersalExtinction-Cladogenesis (DEC, Ree and Smith, 2008; DEC+J, Matzke, 2013a), Bayarealike and Bayarealikej (both modified from Landis et al., 2013) models of geographic (species) range evolution. The four models of range evolution (i.e. DEC, DEC $+\mathrm{J}$, Bayarealike, and Bayarealikej) were implemented in the R package BioGeoBEARS (Matzke, 2013b). Additionally, five scenarios (called M0 to M4) with values of dispersal rate between adjacent areas of 0.50 and 1.00 and dispersal rate between no adjacent areas with values of 1.00, 1.00 E-01, 1.00 E-04, and 1.00 E-20 were tested. Global likelihoods of biogeographic scenarios using the four models were compared using the Akaike Information Criterion (AIC) (Akaike, 1973).

\section{Results}


Partial sequences of two mitochondrial (16SrRNA and CytB) and three nuclear genes (Myh6, Rag1 and Rag2) were obtained for 294 specimens, 26 of which were sequenced in the present study (Table 1). Two matrices were constructed. Matrix 1 included data from all specimens (identified as the Characiformes matrix) containing 4,699 bp, and Matrix 2 included representatives from the Bryconidae, Gasteropelecidae, Triportheidae and selected Characidae (identified as Triportheidae) data totaling 4,666 bp. These matrixes were deposited in TreeBase (www.treebase.org) under the number 17956.

Missing data due to problems with PCR experiments, sequencing, or entries that were not available in GenBank corresponded to $9.7 \%$ of Matrix 1 and to $9.1 \%$ of Matrix 2 (Table 2). Missing data were more prevalent among nuclear loci (16.1\% and $9.1 \%$ for Matrix 1 and 2, respectively) than mitochondrial genes (9.4\% and 9.0\% for Matrix 1 and 2, respectively), possibly due to non-conserved priming regions and a higher risk of cross-contamination in the nested PCR procedure (a few sequences were eliminated from the matrix after contamination was diagnosed by our quality-control protocol). For each matrix and gene, the number and percentage of sequences obtained, size (bp), number of variable sites, base pair composition, overall mean genetic distance ( $\mathrm{p}$ distance), best substitution model for the gene, (shape) parameter of the $\mathrm{C}$ distribution, proportion of invariant (I) sites, number of informative characters under parsimony, and proportion of informative characters under parsimony are presented in Table 2 . The overall mean genetic distance observed was between 0.083 \pm 0.005 (Myh6) and $0.215 \pm 0.007(\mathrm{CytB})($ Matrix 1) and between $0.062 \pm 0.005$ (Myh6) and $0.209 \pm 0.007$ (CytB) (Matrix 2), suggesting that the analyzed sequences exhibited sufficient genetic variation for phylogenetic analyses of species, genera and families. All data were further tested to investigate the occurrence of substitution saturation (Xia et al., 2003; Xia and 
Lemey, 2009), and the results showed no significant saturation. The best-fitting model of nucleotide substitution calculated for each gene is shown in Table 2. The combined data set contains significant phylogenetic information, as most major lineages along the backbone of the tree were supported by high bootstrap values.

\section{TABLE 2}

Six different partitioning schemes ranging from 1 to 13 partitions were tested to establish the optimal number of data partitions (following Li et al., 2008) for the final analysis for each matrix. The results showed that the 13 partition model was the best choice (Table 3). However, ML analysis conducted with the other partitioning schemes produced the same final topology, with minor differences in branch length and support values (data not shown).

\section{TABLE 3}

\subsection{Phylogenetic relationships of the Triportheidae}

As shown in Figure 2, Triportheidae is monophyletic and a sister group of Gasteropelecidae and Bryconidae. Within Triportheidae, Lygnobrycon myersi is the sister group of the remaining members of the family (Fig. 3). A second well-supported group is composed of the two Agoniates species, sister-groups of Clupeacharax anchoveoides, and both as sister-group of Engraulisoma taeniatum (Fig. 3). The third group is composed of all sampled species of Triportheus, which supports the monophyletic status of this genus (Fig. 3). 
FIGURE 2

\subsection{Estimates of divergence times of Triportheidae clades}

We found that the mean substitution rate for the Triportheidae dataset as estimated using BEAST was 0.001847 substitution/site/Myr. The origin of Triportheidae was estimated at $38.9 \pm 10.2 \mathrm{Myr}$ (Fig. 3). Within the Triportheidae, Lignobrycon lineage originated at 29.2 $\pm 3.4 \mathrm{Myr}$, Engraulisoma lineage originated at

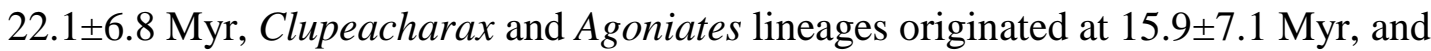
Triportheus lineage originated at 26.2 $\pm 6.5 \mathrm{Myr}$ (Fig. 3).

FIGURE 3

\subsection{Historical Biogeography}

The results for the five biogeographic scenarios tested with BayArea and DEC models show that the $\mathrm{DEC}+\mathrm{J}$ model with dispersal rate between adjacent areas $=1.00$ and dispersal rate between no adjacent areas $=1.00 \mathrm{E}-01$ results in the better hypothesis of ancestral range estimation (Table 4). The better hypothesis suggests that the Triportheidae ancestor was widespread through the Regions A, D, and E at 29.2 \pm 3.4 Myr (Fig. 4) and at 26.2 \pm 6.5 Myr this ancestor was extinct from Region D. Region B was colonized from Region E by an ancestor of Triportheus auritus at 20.7 $\pm 6.5 \mathrm{Myr}$, from Region F by an ancestor of T. albus at $8.9 \pm 4.0 \mathrm{Myr}$, and by an ancestor of $T$.

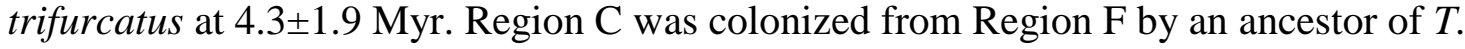
guentheri at 12.4 \pm 4.4 Myr. Region D was colonized again four times, tree from Region E, at 22.1 $\pm 6.8 \mathrm{Myr}$ (Engraulisoma lineage), 15.9 $\pm 7.1 \mathrm{Myr}$ (Clupeacharax lineage), and 4.3 $\pm 1.9 \mathrm{Myr}$ (the ancestor of T. pantanensis and T. angulatus), and one from Region F at 9.5 $\pm 3.6 \mathrm{Myr}$. Region $\mathrm{E}$ was colonized from Region $\mathrm{F}$ by an ancestor of $T$. 
albus at $8.9 \pm 4.0 \mathrm{Myr}$ and by an ancestor of the lineage of $T$. venezuelensis, $T$. pantanensis, T. angulatus, T. trifurcatus, Triportheus sp. nov., and T. signatus at 6.8 \pm 2.7 Myr. Region F was colonized from Region E by an ancestor of T. auritus at 20.7 $\pm 6.5 \mathrm{Myr}$, and by an ancestor of all Triportheus species investigated less $T$. magdalenae, T. culter, and T. rotundatus at 16.0 \pm 5.7 Myr. Region $\mathrm{G}$ was colonized from Region E by an ancestor of T. magdalenae at 6.7 \pm 4.6 Myr. Region $\mathrm{H}$ was colonized from Region E by an ancestor of $T$. signatus at $2.1 \pm 1.4 \mathrm{Myr}$.

FIGURE 4

\section{Discussion}

This study represents the first phylogenetic analysis in which a significant number of Triportheus species along with all other Triportheidae genera were investigated. Our results indicate that the family Triportheidae is monophyletic, as proposed by Oliveira et al. (2011), as are the genera Triportheus and Agoniates.

Our results suggest that Triportheidae is a sister group of Bryconidae and Gasteropelecidae (Fig. 2). According to Weitzman (1954), the presence of expanded coracoids in Triportheus and the so-called subfamily Gasteropelecinae is likely due to convergent evolution, i.e., they arose independently in these groups. This view was adopted by other authors, including Castro and Vari (1990) and Mirande (2010). However, based on morphological analyses, Gregory and Conrad (1938) suggested that "Chalcinus (=Triportheus) is much the nearer to the structural ancestor of Gasteropelecus", a hypotheses rejected in the present study. The close relationship between Bryconidae and Gasteropelecidae as observed here has been suggested in previous studies using molecular markers (Oliveira et al., 2011; Abe et al., 2013) but 
was refuted in Abe et al. (2014), where Triportheidae appears as sister-group of Gasteropelecidae. Considering that the number of species of Triportheidae used in the study of Abe et al. (2014) was small compared with those of Bryconidae and Gasteropelecidae, this result may be due to missing data and taxon sampling artifacts. Further studies involving different markers will be necessary for a better understanding of the relationships of these three families.

In all analyses, Lignobrycon myersi (a single recent species) is the sister group of all remaining Triportheidae, as proposed by Oliveira et al. (2011). The remaining relationships inside Triportheidae proposed by Oliveira et al. (2011) were also corroborated in the present study, even with a significant increase of Triportheus samples. Malabarba (1998) found eight synapomorphies supporting a close relationship between Triportheus and Lignobrycon, but the relationships of these genera with the remaining Triportheidae were not investigated. Thus, it would be informative to revisit the morphological hypothesis within the context of the results arrived at herein.

\section{1 Origin and diversification of the Triportheidae}

The main lineages of Neotropical freshwater fishes were present in South America by the Late Cretaceous, and much of their diversification occurred before or during Paleogene (Lundberg et al., 1998; Albert et al., 2011; Lópes-Fernandez and Albert, 2011). We estimated the origin of all genera in Triportheidae, except Agoniates, in the period corresponding to Early Oligocene to Early Miocene. According to LópezFernandes and Alberts (2011), during the Oligocene, as had occurred before, major marine regressions exposed large areas of interior floodplains, allowing dramatic and sometimes rapid expansions of freshwater habitats including the formation of the socalled "foreland basin" (Lima and Ribeiro, 2011). These events could permit the rapid 
expansion of a primitive Triportheidae through the proto-Paraná and proto-Amazon systems as suggested in our biogeographical analysis (Fig. 4).

Within Triportheidae, the ancestor of all known genera lived in the Regions A (East Coastal Drainages), D (Paraguay and Lower Paraná Basins), and E (Amazon Basin) (Fig. 4), but only the lineage of Lignobrycon remained in the Region A until the present. The ancestor of all other genera lived originally in regions D and E but were soon extinct from Region D, which was recolonized more recently (Fig. 4).

The clade composed of Engraulisoma, Clupeacharax and Agoniates comprises species widely distributed in the Amazon and La Plata basins and the ancestral of this lineage originated at $26.2 \pm 6.5$ (Fig. 3) in the Amazon Basin and from this region its colonized the Paraguay and Lower Paraná Basins two times (Fig. 4). The first dispersion occurred at 22.1 $\pm 6.8 \mathrm{Myr}$ (Engraulisoma lineage) and the second at 15.9 \pm 7.1 Myr (Clupeacharax lineage). The first event coincides with the rise of the Chapare Buttress that divided the paleo-Amazonas-Orinoco and Paraguay basins at 30-20 Myr (Lundberg et al., 1998) and the second event can be due to the shift south to the Michicola Arch at 11.8-10.0 Myr, when important headwater capture of Upper Paraguay by Amazonas occurred (Lundberg et al., 1998).

The ancestor of the genus Triportheus originated at 26.2 \pm 6.5 Myr (Fig. 3). The first lineage to differentiate was that which gave origin to T. auritus at $20.7 \pm 6.5 \mathrm{Myr}$. This species has the widest distribution in the genus (Malabarba, 2004). The ancestor originated in the Amazon Basin and dispersed to Tocantins and Araguaia Basins and Orinoco and North Coastal Drainages (Fig. 4).

Triportheus magdalenae (the single west Andean Triportheidae) from the Magdalena River is the sister group of T. culter from the Juruá River in Amazon (Fig. 3). These two species separated at 6.7 $\pm 4.6 \mathrm{Myr}$ (Fig. 3) and T. magdalenae ancestor 
originated from an ancestor from Amazon Basin (Fig. 4). Abe et al. (2014), found that Salminus sp. from the Amazon basin and S. affinis from Magdalena River Basin separated at 4.1 $\pm 3.7 \mathrm{Myr}$, a similar value to that found here between T. magdalenae and T. culter. The most intense peaks of northern Andean mountain building occurred from the late middle Miocene ( 12 Ma) and early Pliocene ( 4.5 Ma) (Hoorn et al., 2010), which is in accordance with our results on the separation of these two species pairs. Abe et al. (2014) found that Brycon moorei from the Magdalena River basin separated from the other Brycon species at 21.3 $\pm 5.5 \mathrm{Myr}$. This old separation coincides with the first peak of mountain building in the Northern Andes (late Oligocene to early Miocene approximately at $23 \mathrm{Myr}$ ) (Hoorn et al., 2010). Thus, these results suggest that the Magdalene fish fauna diversified over a long period of time, a hypothesis that should be tested with additional data.

The ancestor of the species Triportheus rotundatus from the Amazon basin, the sister group of T. magdalenae and T. culter, originated at 11.0 $\pm 5.4 \mathrm{Myr}$ (Fig. 3). This species is morphologically similar to the species we identified here as $T$. aff. rotundatus from the Paraguay River Basin, which is the sister group of T. nematurus that is also from the Paraguay River Basin (Fig. 3). These two groups belong to different lineages in Triportheus that separated at 16.0 $\pm 5.7 \mathrm{Myr}$ (Fig. 3). This separation may be due to the rise of the Chapare Buttress at 30-20 Myr (Lundberg et al., 1998) or the shift south to the Michicola Arch at 11.8-10.0 Myr (Lundberg et al., 1998). This time is the limit of the age we found for the separation of the $T$. aff. rotundatus lineage from the $T$. rotundatus lineage, but the value is similar to that found by Abe et al. (2014) for the separation of Brycon amazonicus and B. hilarii (12.4 $\pm 5.8 \mathrm{Myr}$ ) and of B. orbygnianus and B. gouldingi (14.4 $\pm 6.3 \mathrm{Myr})$. 
A second species pair from the Amazon and Paraguay basins is Triportheus pantanensis and T. angulatus (Fig. 3). This species pair separated at $2.6 \pm 1.4 \mathrm{Myr}$, an event more recent than that discussed above. However, the formation of the Pantanal Wetland, where we found T. pantanensis, dated to approximately 2.5 Myr (Soares et al., 1998; Assine, 2004). The separation of the species and populations of Upper Paraguay and Amazon at this time were extensively discussed by Ribeiro et al. (2013) using Jupiaba acanthogaster as a model.

Four samples of Triportheus from the Orinoco River were analyzed. Triportheus auritus, as discussed above, is widely distributed in the Amazon Region and is the oldest living Triportheus. Triportheus brachipomus occurs in Orinoco and coastal rivers in north South America (Malabarba, 2004). Our analyses showed that a sample from the Negro River (Amazon Basin) could be morphologically and molecularly identified as $T$. brachipomus. The separation time between the samples from Orinoco and Negro River was 3.6 $\pm 2.4 \mathrm{Myr}$. These data are in accordance with the separation of the Amazon and the Orinoco with the raise of the Vaupes Arch (late Miocene) (Hoorn et al., 1995). These data are also similar to those found in the separation of a sample from Brycon

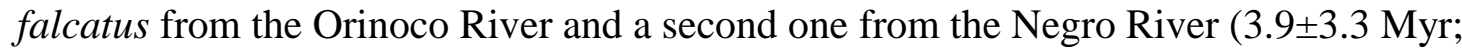
Abe et al., 2014).

The remaining two endemic species of Triportheus from Orinoco, T. orinocensis and T. venezuelensis (Malabarba, 2004), are not sister groups (Fig. 3). The ancestor of T. orinocensis separated from the other Triportheus species at $6.8 \pm 2.7 \mathrm{Myr}$, and the ancestor of T. venezuelensis separated from the other Triportheus species at 5.2 \pm 2.3 Myr (Fig. 3). These times are earlier than those observed between T. brachipomus and Brycon falcatus samples (as discussed above) but are similar to those found by Mariguela et al. (2013) for specimens of Hoplosternum littorale and Megalechis picta 
from the Amazon and the Orinoco, between 11.7 to $6 \mathrm{Myr}$, and are also similar to the separation of T. brachipomus from T. albus (its sister group) that occurred at $6.0 \pm 3.2$ Myr (Fig. 3) suggesting that more than one event separated these two basins or that different species suffered speciation processes in different times.

Triportheus signatus is found in the Parnaíba River basin and some coastal rivers in northeastern Brazil (Malabarba, 2004). In the present study, we used a sample from a tributary of the Parnaíba River and a sample from the Tietê River (Upper Paraná Basin). The data showed that both are identical from the molecular and morphological points of view. This species has been identified as T. nematurus in the Upper Paraná River Basin (e.g. Langeani et al. 2007; Pavanelli et al., 2007) after the review of Malabarba (2004), but is recognized as introduced and even identified as T. signatus in some studies (e.g. Smith et al., 2007). Thus, based on our morphological and molecular analyses, we recognize $T$. signatus as occurring in the Upper Paraná River as an alien species.

Triportheus signatus is the sister group of a putative new species from the Xingu

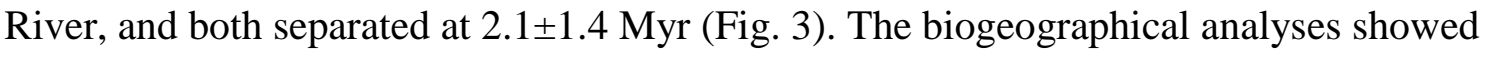
that the ancestor of $T$. signatus originated from the Amazon Basin area (Fig. 4). The ichthyofauna of the Parnaíba River is composed of many endemic species (Ramos et al., 2014), but a relationship between species occurring in this river and in the Amazon Basin has been demonstrated (Vari, 1989). These two species are the sister group of $T$. trifurcatus (endemic of Tocantins-Araguaia Rivers - Malabarba, 2004) and separated from it at 2.9 $\pm 1.6 \mathrm{Myr}$ (Fig. 3). The ancestor of T. trifurcatus also originated in the Amazon Basin region (Fig. 4).

The last group is composed of Triportheus guentheri, T. brachipomus (discussed above) and T. albus (Fig. 3). T. guentheri is the only species of this genus in São 
Francisco. Triportheus albus is found in Amazonas and the Araguaia-Tocantins Rivers (Malabarba, 2004). The ancestor of T. guentheri separated from the ancestor of T. albus and T. brachipomus at $8.9 \pm 4.0 \mathrm{Myr}$ (Fig. 3). Several authors have suggested that the fish fauna of the São Francisco basin is a hybrid combination of groups that occur in adjacent basins (Vari, 1988; Lima and Caires, 2011). Abe et al. (2014) found that Brycon orthotaenia (endemic of the São Francisco River) separated from the other

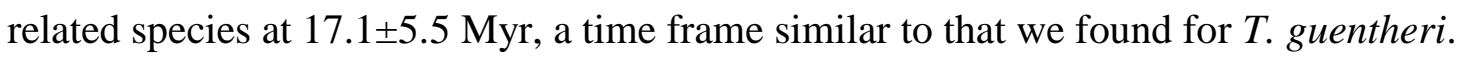

In summary, our results show that: (1) Triportheidae is monophyletic and a sister group of Bryconidae and Gasteropelecidae; (2) Triportheus is monophyletic, but some species need to be reviewed and described; (3) all genera in Triportheidae, less Agoniates, originated in the period between Early Oligocene and Early Miocene; and (4) speciation in Triportheidae coincides with important geological events in South America, reinforcing the use of time-calibrated trees to study fish evolution.

\section{Acknowledgments}

The authors thank all individuals who assisted us in the collection and identification of the specimens that served as the basis for this study, with special thanks to Dr. Mauro Nirchio, Universidad de Oriente, Hernan Ortega, Museo de Historia Natural, Universidad Nacional Mayor de San Marcos, Dr. Oris Sanjur, Smithsonian Tropical Research Institute and Mr. Jorge Enrique García Melo for donations of tissue samples and help in a collection expedition. We give special thanks to Dr. Mônica de Toledo-Piza Ragazzo for his friendly help with species identification and careful manuscript reading and suggestions. TCM is supported by PNPD/Capes. CO is a CNPq (Conselho Nacional de Desenvolvimento Científico e Tecnológico do Brasil) researcher (CNPq grant number 309632/2007-2, FAPESP 2014/05051-5 to FFR). 


\section{References}

Abe, K.T, Mariguela, T.C., Avelino, G.S., Foresti, F., Oliveira, C., 2014. Systematic and historical biogeography of the Bryconidae (Ostariophysi: Characiformes) suggesting a new rearrangement of its genera and an old origin of Mesoamerican ichthyofauna. BMC Evol. Biol., 14, 152-167.

Abe, K.T., Mariguela, T.C., Avelino, G.S., Castro, R.M.C., Oliveira, C., 2013. Multilocus molecular phylogeny of Gasteropelecidae (Ostariophysi: Characiformes) reveals the existence of an unsuspected diversity. Mol. Phyl. Evol., 69, 1209-1214.

Akaike, H., 1973. Information theory and an extension of the maximum likelihood principle. In: Petrov, B.N., Czaki, F. (Eds) 2nd International Symposium on Information Theory. Budapest: Akademiai Kiad6, 267-281.

Albert, J.S, Petry, P., Reis, R.E., 2011. Major Biogeographic and Phylogenetic Patterns. In Albert, J.S., Reis, R.E. (Eds.). Historical Biogeography of Neotropical Freshwater Fishes. University of California Press, Berkeley, pp. 21-59.

Arroyave, J., Stiassny, M.L.J., 2011. Phylogenetic relationships and the temporal context for the diversification of African characins of the family Alestidae (Ostariophysi: Characiformes): Evidence from DNA sequence data. Mol. Phyl. Evol., 60, 385-397.

Assine, M.L., 2004. A bacia sedimentar do Pantanal Mato-Grossense. In MantessoNeto, V., Bartorelli, A., Carneiro, C.D.R., Brito-Neves, B.B. (Eds.). Geologia do Continente Sul-Americano: Evolução da Obra de Fernando Flávio Marques de Almeida. Editora Beca, São Paulo, pp. 61-74. 
Castro, R.M.C., Vari, R.P., 1990. Moojenichthys Miranda-Ribeiro (Pisces:

Ostariophysi: Characidae), a phylogenetic reapraisal and redescription. Proc. Biol. Soc. Wash., 103, 525-542.

Drummond, A.J., Suchard, M.A., Xie, D. Rambaut, A., 2012. Bayesian phylogenetics with BEAUti and the BEAST 1.7. Mol. Biol. Evol., 29, 1969-1973.

Edgar, R.C., 2004. MUSCLE: a multiple sequence alignment method with reduced time and space complexity. BMC Bioinformatics, 5, 113.

Eschmeyer, W.N., Fong, J.D., 2015. Species by family/subfamily. (http://research.calacademy.org/research/ichthyology/catalog/SpeciesByFamily.asp) . Electronic version accessed 10/07/2015.

Gregory, W.K., Conrad, G.M., 1938. The phylogeny of the characin fishes. Zoologica, 23, 319-360.

Hall, T.A., 1999. BioEdit: a user-friendly biological sequence alignment editor and analysis program for Windows 95/98/NT. Nucl. Acids Symp. Ser., 41, 95-98.

Hoorn, C., Guerrero, J., Sarmiento, G.A., Lorente, M.A., 1995. Andean Tectonics as a Cause for Changing Drainage Patterns in Miocene Northern South-America. Geology, 23, 237-240.

Hoorn, C., Wesselingh, F.P., ter Steege, H., Bermudez, M.A., Mora, A., Sevink, J., Sanmartín, I., Sanchez-Meseguer, A., Anderson, C.L., Figueiredo, J.P., Jaramillo, C., Riff, D., Negri, F.R., Hooghiemstra, H., Lundberg, J., Stadler, T., Särkinen, T., Antonelli, A., 2010. Amazonia Through Time: Andean Uplift, Climate Change, Landscape Evolution, and Biodiversity. Science, 33, 927-931.

Landis, M. J., Matzke, N. J., Moore, B. R., Huelsenbeck, J. P., 2013. Bayesian analysis of biogeography when the number of areas is large. Syst. Biol., syt040. 
Langeani, F., Castro, R.M.C., Oyakawa, O.T., Shibatta, O.A., Pavanelli, C.S., Casatti, L., 2007. Diversidade da ictiofauna do Alto Rio Paraná: composição atual e perspectivas futura. Biota Neotrop, 7, 181-197.

Li, C., Lu, G., Ortí, G., 2008. Optimal data partitioning and a test case for ray-finned fishes (Actinopterygii) based on ten nuclear loci. Syst. Biol., 57, 519-539.

Li, C., Ortí, G., Zhang, G., Lu, G., 2007. A practical approach to phylogenomics: The phylogeny of ray-finned fish (Actinopterygii) as a case study. BMC Evol. Biol., 7, 44.

Lima, F.C.T., Caires, R.A., 2011. Peixes da Estação Ecológica Serra Geral do Tocantins, bacias dos Rios Tocantins e São Francisco, com observações sobre as implicações biogeográficas das “águas emendadas” dos Rios Sapão e Galheiros. Biota Neotrop., 11, 231-250.

Lima, M.R., Salard-Cheboldaeff, M., Suguio, K., 1985. Etude palynilogique de la formation Tremembé, Tertiaire du Bassin de Taubaté, (Etat de São Paulo, Bresil), d'apres les echantillons du sondage n-42 du CNP. Coletânea de Trabalhos Paleontológicos, MME-DNPM. Sér zool, 27, 379-393.

Lima, F.C.T., Ribeiro, A.C., 2011. Continental-scale tectonic controls of biogeography and ecology. In Albert, J.S., Reis, R.E. (Eds.). Historical Biogeography of Neotropical Freshwater Fishes. University of California Press, Berkeley, pp. 145164.

Lopez-Fernández, H., Albert, J.S., 2011. Paleogene Radiations. In Albert, J.S., Reis, R.E. (Eds.). Historical Biogeography of Neotropical Freshwater Fishes. University of California Press, Berkeley, pp. 105-117.

Lundberg, J.G., Marshall, L.G., Guerrero, J., Horton, B., Malabarba, M.C.S.L., Wesselingh, F., 1998. The stage for Neotropical fish diversification: a history of 
tropical South American rivers. In Malabarba, L.R., Reis, R.E., Vari, R.P., Lucena, Z.M.S., Lucena, C.A.S. (Eds.). Phylogeny and classification of Neotropical fishes. EDIPUCRS, Porto Alegre, pp. 13-48.

Malabarba, M.C.S.L., 1998. Phylogeny of fossil Characiformes and paleobiogeography of the Tremembé Formation, São Paulo, Brazil. In Malabarba, L.R., Reis, R.E., Vari, R.P., Lucena, Z.M.S., Lucena, C.A.S. (Eds.). Phylogeny and Classification of Neotropical Fishes. Edipucrs, Porto Alegre, pp. 69-84.

Malabarba, M.C.S.L., 2004. Revision of the Neotropical genus Triportheus Cope, 1872 (Characiformes, Characidae). Neotrop. Ichthyol., 2, 167-204.

Mariguela, T.C., Alexandrou, M.A., Foresti, F., Oliveira, C., 2013. Historical biogeography and cryptic diversity in the Callichthyinae (Siluriformes, Callichthyidae). J. Zoolog. Syst. Evol. Res., 51, 308-315.

Matzke, N.J., 2013a. Probabilistic historical biogeography: new models for founderevent speciation, imperfect detection, and fossils allow improved accuracy and model-testing. Front. Biogeogr., 5, 242-248.

Matzke, N.J. 2013b. BioGeoBEARS: BioGeography with Bayesian (and Likelihood) Evolutionary Analysis in R Scripts. Release R package version 0.2.2-2. http://CRAN.R-project.org/package=BioGeoBEARS.

Miller, M.A., Pfeiffer, W., Schwartz, T., 2010. Creating the CIPRES Science Gateway for inference of large phylogenetic trees. Proc. Gat. Comp. Environm. Workshop (GCE), New Orleans, LA pp. 1-8.

Mirande, J.M., 2010. Phylogeny of the family Characidae (Teleostei: Characiformes): from characters to taxonomy. Neotrop. Ichthyol., 8, 385-568.

Oliveira, C., Avelino, G.S., Abe, K.T., Mariguela, T.C., Benine, R.C., Ortí, G., Vari, R.P., Castro, R.M.C., 2011. Phylogenetic relationships within the speciose family 
Characidae (Teleostei: Ostariophysi: Characiformes) based on multilocus analysis and extensive ingroup sampling. BMC Evol. Biol., 11, 275.

Parham, J.F., Donoghue, P.C.J., Bell, C.J., Calway, T.D., et al., 2012. Best practices for justifying fossil calibrations. Syst. Biol., 61, 346-359.

Pavanelli, C.S., Graça, W.J., Zawadzki, C.H., Britski, H.A., Vidotti, A.P., Avelino, G.S., Veríssimo, S., 2007. Fishes from the Corumbá Reservoir, Paranaíba River drainage, upper Paraná River basin, State of Goiás, Brazil. Check List, 3, 58-64

Posada, D., Buckley, T.R., 2004. Model selection and model averaging in phylogenetics: advantages of Akaike information criterion and Bayesian approaches over likelihood ratio tests. Syst. Biol., 53, 793-808.

Rambaut, A., 2014. FigTree v. 1.4.2. http://tree.bio.ed.ac.uk/software/figtree.

Rambaut, A., Drummond, A.J., 2007a. Tracer v1.5, Available from http://beast.bio.ed.ac.uk/Tracer.

Rambaut, A., Drummond, A.J., 2007b. TreeAnnotator v1.8.0. Available from http://beast.bio.ed.ac.uk/TreeAnnotator.

Ramos, T.P.A., Ramos, R.T.C., Ramos, S.A.Q.A., 2014. Ichthyofauna of the Parnaíba River Basin, Northeastern Brazil. Biota Neotrop., 14, 1-8.

Ree, R.H., Smith, S.A., 2008. Maximum likelihood inference of geographic range evolution by dispersal, local extinction, and cladogenesis. Syst. Biol., 57, 4-14.

Ribeiro, A.C., Jacob, R.M., Silva, R.R.S.R., Lima, F.C.T., Ferreira, D.C., Ferreira, K.M., Mariguela, T.C., Pereira, L.H.G., Oliveira, C., 2013. Distributions and phylogeographic data of rheophilic freshwater fishes provide evidences on the geographic extension of a central-brazilian Amazonian palaeoplateau in the area of the present day Pantanal Wetland. Neotrop. Ichthyol., 11, 319-326. 
Riccomini, C., Suguio, K., Alvarenga, H., Fittipaldi, F., 1991. Estratigrafia e ambientes de sedimentação da porção central da Bacia de Taubaté. Congresso Brasileiro de Paleontologia, 12, 1-29.

Smith, W.S., Petrere Jr., M., Barrella, V., 2007. Fish, Sorocaba river sub-basin, state of São Paulo, Brazil. Check List, 3, 282-286.

Soares, P.C., Assine, M.L., Rabelo, L., 1998. The Pantanal Basin: Recent tectonics, relationships to the Transbrasiliano Lineament. Anais IX Simpósio Brasileiro de Sensoriamento Remoto, Santos: INPE, pp. 459-469.

Soria, M.F., Alvarenga, H., 1989. Nuevos restos de mamiferos de la Cuenca de Taubaté, Estado de São Paulo, Brasil. An. Acad. Brasil. Cienc., 61, 157-175.

Stamatakis, A., 2006. RAxML-VI-HPC: Maximum likelihood-based phylogenetic analyses with thousands of taxa and mixed models. Bioinformatics, 22, 2688-2690.

Stamatakis, A., Hoover, P., Rougemont, J., 2008. A rapid bootstrap algorithm for the RAxML web servers. Syst. Biol., 57, 758-771.

Tamura, K., Peterson, D., Peterson, N., Stecher, G., Nei, M., Kumar, S., 2011. MEGA5: Molecular Evolutionary Genetics Analysis using Maximum Likelihood, Evolutionary Distance, and Maximum Parsimony Methods. Mol. Biol. Evol., 28, 2731-2739.

Tavaré, S., 1986. Some Probabilistic and Statistical Problems in the Analysis of DNA Sequences. Lectt. Math. Life Science. \& Am. Math. Soc. 17, 57-86.

Vari, R.P., 1988. The Curimatidae, a lowland Neotropical fish family (Pisces: Characiformes); distribution, endemism, and phylogenetic biogeography. In Vanzolini, P.E., Heyer, W.R. (Eds.). Proceedings of a Workshop on Neotropical Distribution Patterns. Academia Brasileira de Ciências, Rio de Janeiro, pp. 343377. 
Vari, R.P., 1989. Systematics of the Neotropical characiform genus Psectrogaster Eigenmann and Eigenmann (Pisces, Characiformes). Smithsonian Contributions to Zoology, 481, 1-41.

Vari, R.P., Malabarba, L.R. 1998. Neotropical ichthyology: An overview. In:

Malabarba, L.R., Reis, R.E., Vari, R., Lucena, Z.M.S., Lucena, C.A.S. (Eds.). Phylogeny and Classification of Neotropical Fishes. Edipucrs, Porto Alegre, pp. 111.

Weitzman, S.H., 1954. The osteology and relationships of the South American characoid fishes of the subfamily Gasteropelecinae. Stanford Ichthyol. Bull., 4, $213-263$.

Xia, X., Lemey, P., 2009. Assessing substitution saturation with DAMBE. In Lemey, P., Salemi, M., Vandamme, A. M. (Eds.). The Phylogenetic Handbook: A Practical Approach to DNA and Protein Phylogeny, 2nd edition, Cambridge University Press, pp. 615-630.

Xia, X., Xie, Z., 2001. DAMBE: Data analysis in molecular biology and evolution. J Heredity, 92, 371-373.

Xia, X., Xie, Z., Salemi, M., Chen, L., Wang, Y., 2003. An index of substitution saturation and its application. Mol. Phyl. Evol., 26, 1-7.

\section{Table legends}

Table 1 Species of Triportheidae analyzed in the present study. Asterisks indicate specimens sequenced in Oliveira et al. (2011).

Table 2 Information content and characteristics of each molecular data partition. The upper line represents the values of Matrix 1 (total dataset), and the lower line represents 
the values of Matrix 2 (Triportheidae + Bryconidae + Gasteropelecidae + select Characidae).

Table 3 Comparison of log likelihoods and AIC and BIC values among different partitioning schemes (from 1 to 13 partitions) for Matrix 1 (all data) and Matrix 2 (Triportheidae + Bryconidae + Gasteropelecidae + selected Characidae). For each type of analysis, the following results are shown: total number of parameters, log likelihood calculated using RAxML $\left(L_{M L}\right)$, AIC values, the difference in AIC values among model $\mathrm{i}$ and the best model $(\Delta i=\mathrm{AIC} i-\mathrm{AICmin})$, and $\mathrm{BIC}_{M L}$ values.

Table 4. Maximum likelihood estimates for five biogeography scenarios indicates the $\mathrm{DEC}+\mathrm{J}$ model range evolution best optimize (i.e. maximize likelihood) the geographical distribution of Triportheidae species under the model M4. Abbreviations: LEM, landscape evolution model; GRE, geographical range evolution; DEC, dispersalextinction-cladogenesis; ln L, log likelihood; K, parameters; d, dispersal; $\mu$, extinction; j, cladogenesis per-event weights; AIC, Akaike information criterion; AIC, $\Delta$ delta AIC.

\section{Figure Captions}
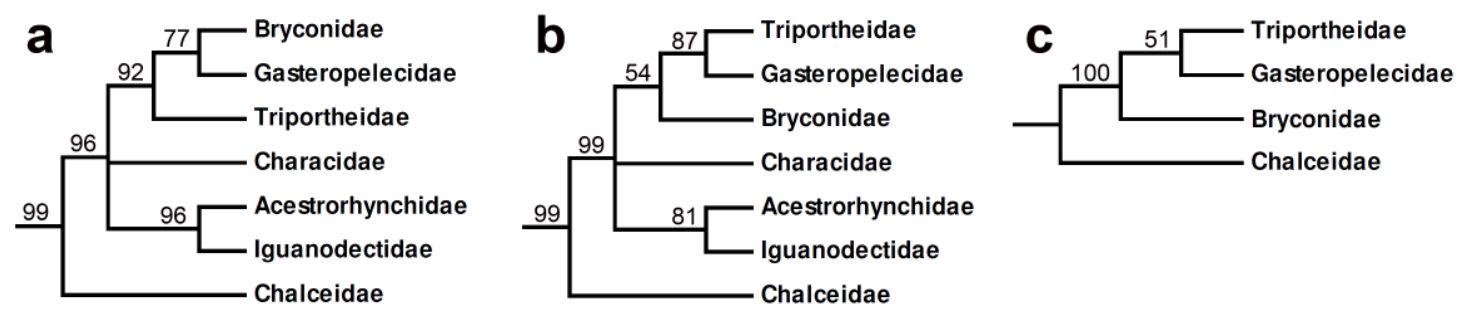

Fig. 1 Maximum likelihood trees showing the relationships among Triportheidae,

Bryconidae and Gasteropelecidae according to Oliveira et al. (2011) (a), Abe et al. (2014) (b), and Abe et al. (2013) (c). Numbers represent bootstrap values obtained in 1,000 pseudoreplicates. 


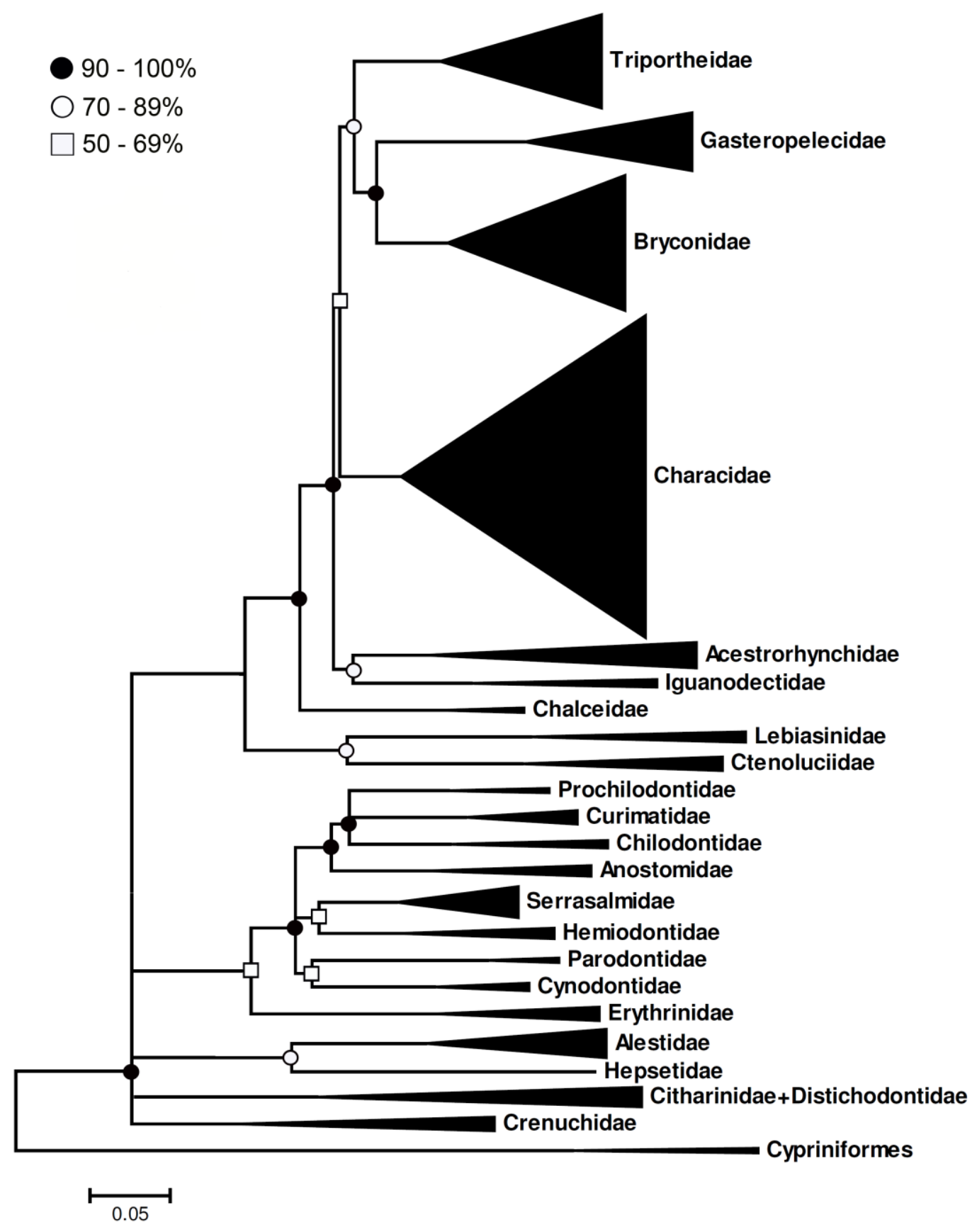

Fig. 2 Maximum likelihood tree obtained in the partitioned analysis showing relationships among Characiformes families. 


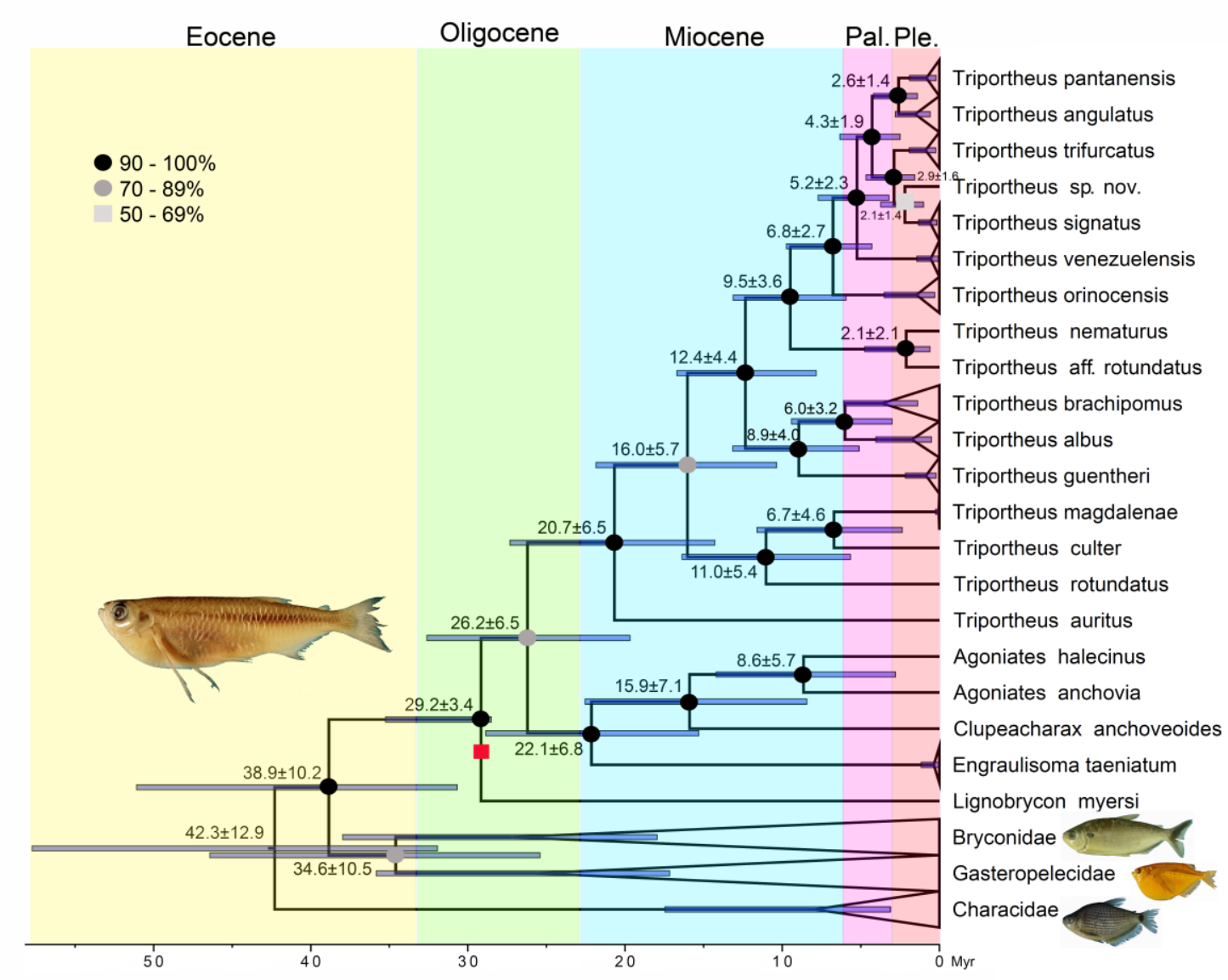

Fig. 3 Time-calibrated phylogeny obtained using BEAST from 15 million generations indicating the divergence over time of the family Triportheidae. The red square shows the calibration point based on the fossil of Lignobrycon ligniticus (28.5 $\pm 5.5 \mathrm{Myr})$. Scale $=$ millions of years before present. Node bars $=$ Node height highest posterior density $(\mathrm{HPD})$ intervals at $95 \%$. Node numbers $=$ node ages \pm Node height $95 \%$ HPD. 


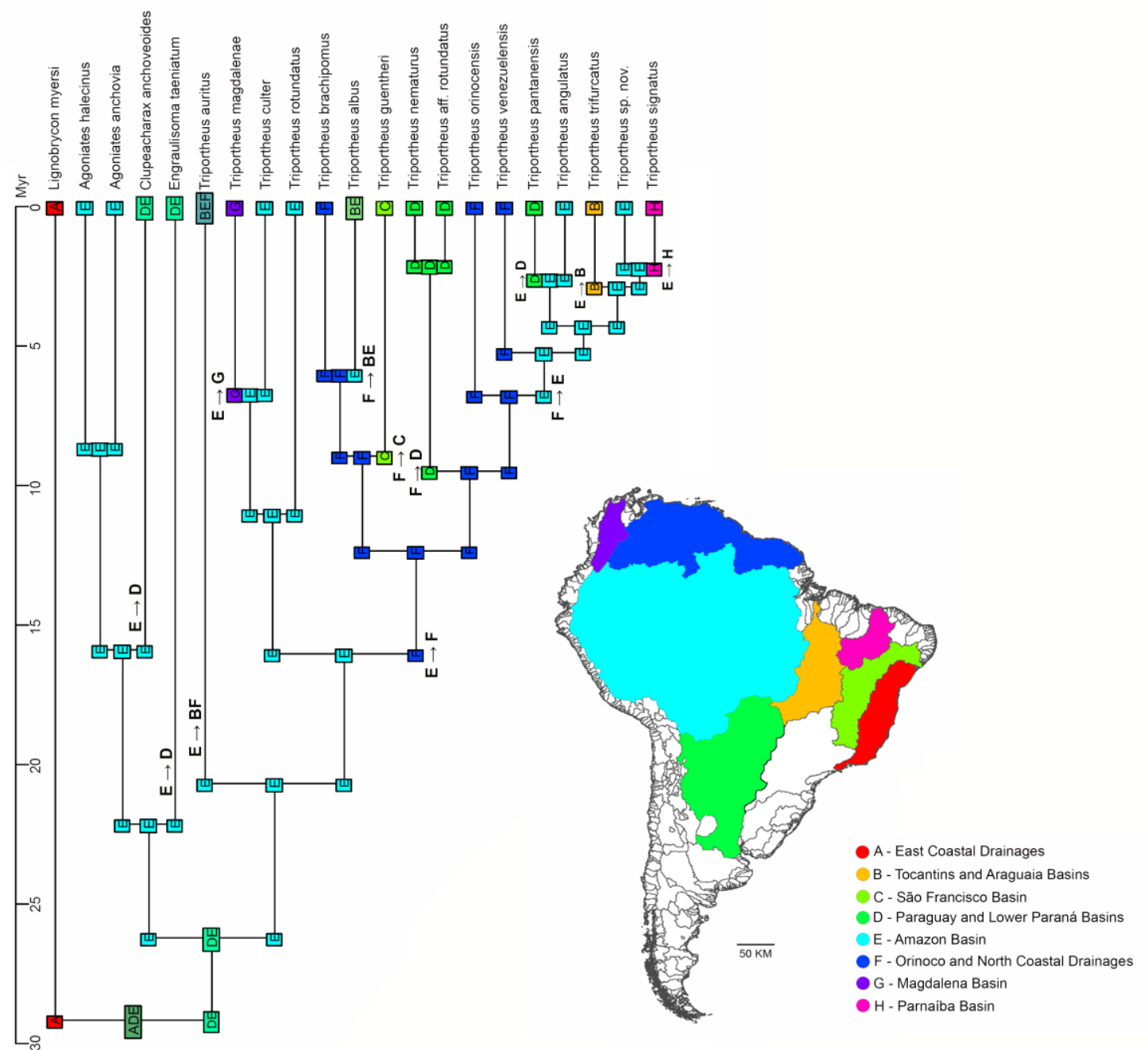

Fig. 4. Ancestral range estimation for Triportheidae using DEC+J model. Color changes between squares indicate dispersal and/or extinction events. Different colors represent species present in multiple geographical areas. 


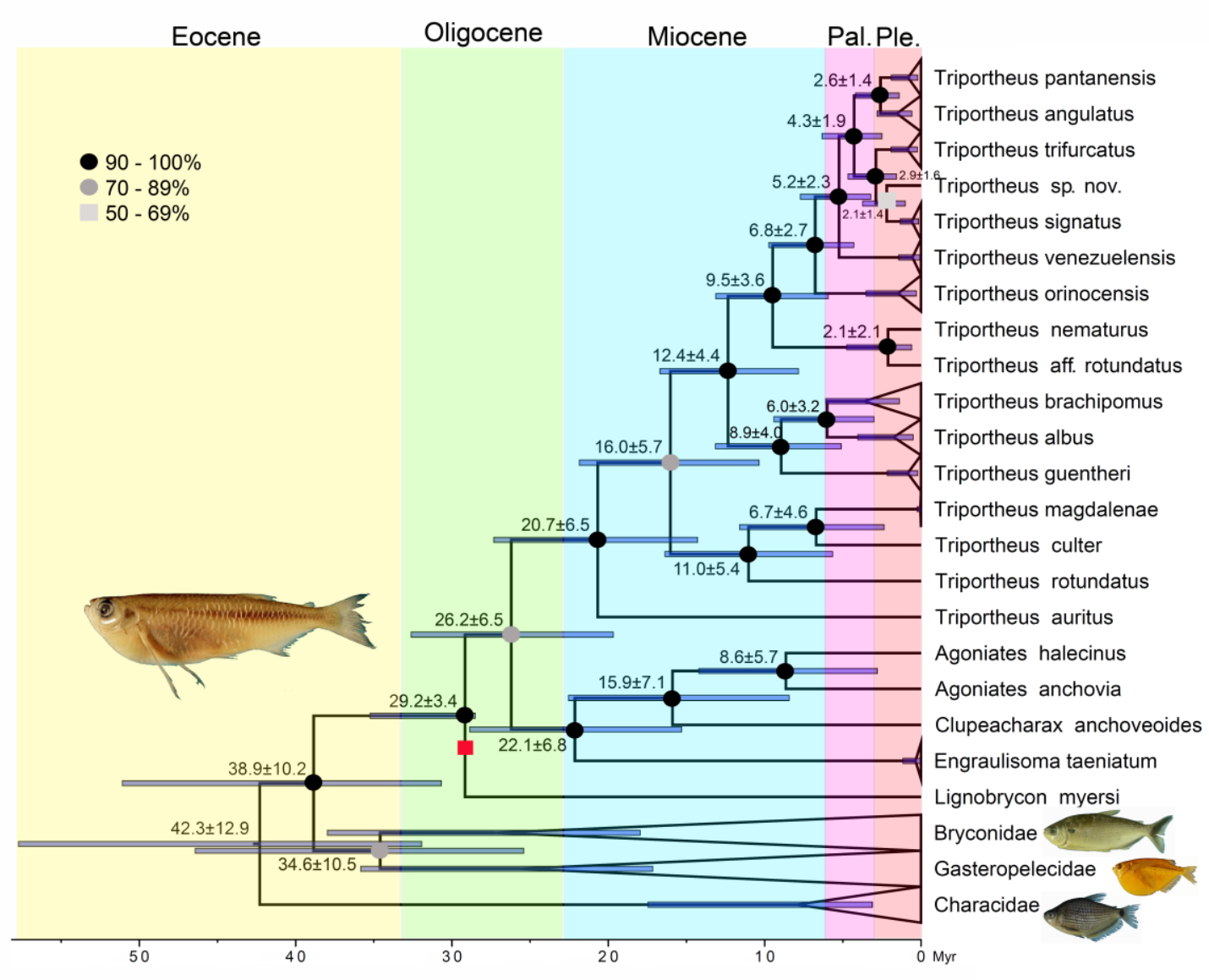


Table 1 Triportheidae species analyzed in the present study. Asterisks indicate specimens sequenced in Oliveira et al. (2011).

\begin{tabular}{|c|c|c|c|c|c|c|c|c|c|}
\hline Species & $\begin{array}{c}\text { Vouche } \\
\text { r }\end{array}$ & $\begin{array}{c}\text { Specime } \\
n\end{array}$ & Locality & Geographic position & $16 S$ & CytB & Myh6 & Rag1 & Rag2 \\
\hline $\begin{array}{l}\text { Agoniates } \\
\text { anchovia* }^{*}\end{array}$ & LBP6740 & 33471 & Lago Catalão/Manaus/AM/Brazil & $\begin{array}{l}\text { S } 03^{\circ} 09.761^{\prime} \\
\text { W } 59^{\circ} 54.487^{\prime}\end{array}$ & $\begin{array}{c}\text { HQ17137 } \\
8\end{array}$ & $\begin{array}{c}\text { HQ28966 } \\
5\end{array}$ & - & - & $\begin{array}{c}\text { HQ28947 } \\
2\end{array}$ \\
\hline $\begin{array}{l}\text { Agoniates } \\
\text { halecinus* }\end{array}$ & LBP5503 & 26594 & Igarapé Uiratapuru/Laranjal do Jari/AP/Brazil & $\begin{array}{l}\text { S } 00^{\circ} 34^{\prime} 03^{\prime \prime} \\
\text { W } 52^{\circ} 34^{\prime} 41^{\prime \prime}\end{array}$ & $\begin{array}{c}\text { HQ17134 } \\
2\end{array}$ & $\begin{array}{c}\text { HQ28963 } \\
1\end{array}$ & $\begin{array}{c}\text { HQ28905 } \\
1\end{array}$ & $\begin{array}{c}\text { HQ28928 } \\
0\end{array}$ & $\begin{array}{c}\text { HQ28943 } \\
7\end{array}$ \\
\hline $\begin{array}{l}\text { Engraulisom } \\
\text { a taeniatum } *\end{array}$ & LBP4038 & 22896 & Rio Moa/Cruzeiro do Sul/AC/ Brazil & $\begin{array}{l}\text { S 7 } 77^{\circ} 20.0^{\prime \prime} \\
\text { W } 72^{\circ} 47^{\prime} 42.2^{\prime \prime}\end{array}$ & $\begin{array}{c}\text { HQ17133 } \\
7\end{array}$ & $\begin{array}{c}\text { HQ28962 } \\
6\end{array}$ & $\begin{array}{c}\text { HQ28904 } \\
6\end{array}$ & $\begin{array}{c}\text { HQ28923 } \\
9\end{array}$ & $\begin{array}{c}\text { HQ28943 } \\
3\end{array}$ \\
\hline $\begin{array}{l}\text { Engraulisom } \\
\text { a taeniatum* } \\
\text { Clupeachara }\end{array}$ & LBP4038 & 22897 & Rio Moa/Cruzeiro do Sul/AC/ Brazil & $\begin{array}{l}\text { S } 7^{\circ} 37^{\prime} 20.0^{\prime \prime} \\
\text { W } 72^{\circ} 47^{\prime} 42.2^{\prime \prime}\end{array}$ & $\begin{array}{c}\text { HQ17129 } \\
9\end{array}$ & $\begin{array}{c}\text { HQ2 } 2958 \\
8\end{array}$ & $\begin{array}{c}\text { HQ2 } 8900 \\
9\end{array}$ & - & - \\
\hline $\begin{array}{l}x \\
\text { anchoveoides } \\
*\end{array}$ & LBP5046 & 26012 & Lagoa Bairro Caiçara/Cáceres/MT/Brazil & $\begin{array}{l}\text { S } 16^{\circ} 06^{\prime} 56^{\prime} \\
\text { W } 57^{\circ} 44^{\prime} 33^{\prime \prime}\end{array}$ & $\begin{array}{c}\text { HQ17130 } \\
0\end{array}$ & $\begin{array}{c}\text { HQ28958 } \\
9\end{array}$ & $\begin{array}{l}\text { HQ28901 } \\
0\end{array}$ & - & - \\
\hline $\begin{array}{l}\text { Lignobrycon } \\
\text { myersi* }\end{array}$ & LBP8094 & 37519 & Rio do Braço/Ihéus/BA/Brazil & $\begin{array}{l}\mathrm{S} 14^{\circ} 41^{\prime} 11.7^{\prime} \mathrm{W} \\
39^{\circ} 16^{\prime} 28.0^{\prime \prime}\end{array}$ & $\begin{array}{c}\text { HQ17140 } \\
2\end{array}$ & $\begin{array}{l}\text { HQ28968 } \\
9\end{array}$ & $\begin{array}{c}\text { HQ28911 } \\
0\end{array}$ & $\begin{array}{c}\mathrm{HQ} 28930 \\
3\end{array}$ & - \\
\hline $\begin{array}{l}\text { Triportheus } \\
\text { albus }\end{array}$ & LBP8806 & 44141 & $\begin{array}{l}\text { Lagoa do Japonês/Rio } \\
\text { Araguaia/Cocalinho/MT/Brazil }\end{array}$ & $\begin{array}{l}\mathrm{S} 13^{\circ} 26^{\prime} 19.4^{\prime} \mathrm{W} \\
50^{\circ} 39^{\prime} 46.4^{\prime \prime}\end{array}$ & $\begin{array}{c}\mathrm{KT} 28118 \\
2\end{array}$ & $\begin{array}{c}\text { KT28119 } \\
8\end{array}$ & $\begin{array}{c}\text { KT2 } 28122 \\
6\end{array}$ & $\begin{array}{c}\mathrm{KT} 28124 \\
4\end{array}$ & $\begin{array}{c}\text { KT28126 } \\
7\end{array}$ \\
\hline $\begin{array}{l}\text { Triportheus } \\
\text { albus }\end{array}$ & LBP8806 & 44144 & $\begin{array}{c}\text { Lagoa do Japonês/Rio } \\
\text { Araguaia/Cocalinho/MT/Brazil }\end{array}$ & $\begin{array}{l}\text { S } 13^{\circ} 26^{\prime} 19.4^{\prime} \mathrm{W} \\
50^{\circ} 39^{\prime} 46.4^{\prime \prime}\end{array}$ & $\begin{array}{c}\text { KT2 } 28118 \\
3\end{array}$ & $\begin{array}{c}\text { KT2 } 28121 \\
2\end{array}$ & $\begin{array}{c}\text { KT28122 } \\
5\end{array}$ & $\begin{array}{c}\text { KT2 } 28125 \\
8\end{array}$ & $\begin{array}{c}\text { KT28128 } \\
2\end{array}$ \\
\hline $\begin{array}{l}\text { Triportheus } \\
\text { angulatus }\end{array}$ & LBP4213 & 22743 & Rio Juruá/Cruzeiro do Sul/AC/Brazil & $\begin{array}{l}\text { S } 07^{\circ} 09^{\prime} 49.6^{\prime} \mathrm{W} \\
73^{\circ} 43^{\prime} 29.7^{\prime \prime}\end{array}$ & $\begin{array}{c}\mathrm{KT} 28117 \\
4\end{array}$ & $\begin{array}{c}\text { KT2 } 28119 \\
6\end{array}$ & $\begin{array}{c}\text { KT2 } 28123 \\
2\end{array}$ & $\begin{array}{c}\text { KT28124 } \\
2\end{array}$ & $\begin{array}{c}\text { KT28126 } \\
5\end{array}$ \\
\hline $\begin{array}{l}\text { Triportheus } \\
\text { angulatus }\end{array}$ & $\begin{array}{c}\text { LBP1059 } \\
3\end{array}$ & 49353 & Igarapé São Francisco/Rio Branco/AC/Brazil & $\begin{array}{l}\text { S } 09^{\circ} 56^{\prime} 16.6^{\prime \prime} \mathrm{W} \\
67^{\circ} 52^{\prime} 48.6^{\prime \prime}\end{array}$ & $\begin{array}{c}\text { KT28118 } \\
8\end{array}$ & $\begin{array}{c}\text { KT28120 } \\
7\end{array}$ & $\begin{array}{c}\text { KT28123 } \\
3\end{array}$ & $\begin{array}{c}\mathrm{KT} 28125 \\
3\end{array}$ & $\begin{array}{c}\text { KT28127 } \\
7\end{array}$ \\
\hline $\begin{array}{l}\text { Triportheus } \\
\text { auritus }\end{array}$ & LBP3052 & 19160 & $\begin{array}{c}\text { Rio Orinoco/Caicara del } \\
\text { Orinoco/Bolivar/Venezuela }\end{array}$ & $\begin{array}{l}\text { N } 07^{\circ} 38^{\prime} 11.6^{\prime \prime} \mathrm{W} \\
66^{\circ} 19^{\prime} 04.2^{\prime \prime}\end{array}$ & $\begin{array}{c}\text { KT28116 } \\
9\end{array}$ & $\begin{array}{c}\text { KT28119 } \\
3\end{array}$ & $\begin{array}{c}\text { KT28121 } \\
7\end{array}$ & $\begin{array}{c}\text { KT28123 } \\
9\end{array}$ & $\begin{array}{c}\text { KT28126 } \\
3\end{array}$ \\
\hline $\begin{array}{l}\text { Triportheus } \\
\text { brachipomus }\end{array}$ & LBP4426 & 24305 & Rio Negro/Barcelos/AM/Brazil & $\begin{array}{l}\mathrm{S} 00^{\circ} 55^{\prime} 30.0^{\prime \prime} \mathrm{W} \\
62^{\circ} 51^{\prime} 51.4^{\prime \prime}\end{array}$ & $\begin{array}{c}\text { KT28117 } \\
5\end{array}$ & $\begin{array}{c}\text { KT2 } 28120 \\
4\end{array}$ & $\begin{array}{c}\mathrm{KT} 28122 \\
7\end{array}$ & $\begin{array}{c}\text { KT28125 } \\
0\end{array}$ & $\begin{array}{c}\text { KT28127 } \\
3\end{array}$ \\
\hline $\begin{array}{l}\text { Triportheus } \\
\text { brachipomus }\end{array}$ & $\begin{array}{l}\text { LBP1016 } \\
7\end{array}$ & 47590 & Rio Apure/Cabruta/Guárico/Venezuela & $\begin{array}{l}\text { N } 07^{\circ} 37^{\prime} 24.4^{\prime} \mathrm{W} \\
66^{\circ} 24^{\prime} 48.0^{\prime \prime}\end{array}$ & $\begin{array}{c}\text { KT28118 } \\
7\end{array}$ & $\begin{array}{c}\text { KT2 } 28120 \\
6\end{array}$ & $\begin{array}{c}\mathrm{KT} 28122 \\
1\end{array}$ & $\begin{array}{c}\mathrm{KT} 28125 \\
2\end{array}$ & $\begin{array}{c}\text { KT28127 } \\
5\end{array}$ \\
\hline $\begin{array}{l}\text { Triportheus } \\
\text { culter }\end{array}$ & $\begin{array}{l}\text { LBP1192 } \\
0\end{array}$ & 22709 & Rio Juruá/Cruzeiro do Sul/AC/Brazil & 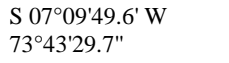 & $\begin{array}{c}\text { KT28117 } \\
3\end{array}$ & $\begin{array}{c}\text { KT28121 } \\
4\end{array}$ & $\begin{array}{c}\text { KT28122 } \\
0\end{array}$ & $\begin{array}{c}\text { KT28126 } \\
0\end{array}$ & $\begin{array}{c}\text { KT28127 } \\
6\end{array}$ \\
\hline $\begin{array}{l}\text { Triportheus } \\
\text { guentheri }\end{array}$ & $\begin{array}{l}\text { LBP1029 } \\
3\end{array}$ & 42910 & $\begin{array}{c}\text { Baia da Inhuma/Rio São Francisco/São Roque de } \\
\text { Minas/MG/Brazil }\end{array}$ & $\begin{array}{l}\mathrm{S} 20^{\circ} 11^{\prime} 03.4^{\prime} \mathrm{W} \\
45^{\circ} 50^{\prime} 57.9^{\prime \prime}\end{array}$ & $\begin{array}{c}\text { KT28118 } \\
0\end{array}$ & $\begin{array}{c}\text { KT28119 } \\
5\end{array}$ & $\begin{array}{c}\text { KT28122 } \\
4\end{array}$ & $\begin{array}{c}\text { KT28124 } \\
1\end{array}$ & $\begin{array}{c}\text { KT28126 } \\
4\end{array}$ \\
\hline $\begin{array}{l}\text { Triportheus } \\
\text { guentheri }\end{array}$ & $\begin{array}{l}\text { LBP1029 } \\
3\end{array}$ & 47240 & $\begin{array}{c}\text { Baia da Inhuma/Rio São Francisco/São Roque de } \\
\text { Minas/MG/Brazil }\end{array}$ & $\begin{array}{l}\mathrm{S} 20^{\circ} 11^{\prime} 03.4^{\prime} \mathrm{W} \\
45^{\circ} 50^{\prime} 57.9^{\prime \prime}\end{array}$ & $\begin{array}{c}\text { KT2 } 28118 \\
6\end{array}$ & $\begin{array}{c}\text { KT2 } 28120 \\
3\end{array}$ & $\begin{array}{c}\text { KT28122 } \\
6\end{array}$ & $\begin{array}{c}\text { KT2 } 28124 \\
9\end{array}$ & $\begin{array}{c}\text { KT28127 } \\
2\end{array}$ \\
\hline $\begin{array}{l}\text { Triportheus } \\
\text { magdalenae }\end{array}$ & $\begin{array}{l}\text { LBP1899 } \\
3\end{array}$ & 75307 & $\begin{array}{c}\text { Rio Coelho/Rio } \\
\text { Magdalena/Coelho/Tolima/Colombia }\end{array}$ & $\begin{array}{l}\text { N } 04^{\circ} 17^{\prime} 25.4^{\prime \prime} \mathrm{W} \\
74^{\circ} 533^{\prime} 28.1^{\prime \prime}\end{array}$ & $\begin{array}{c}\mathrm{KT} 28119 \\
2\end{array}$ & $\begin{array}{c}\text { KT2 } 28121 \\
6\end{array}$ & - & $\begin{array}{c}\text { KT2 } 28126 \\
2\end{array}$ & - \\
\hline $\begin{array}{l}\text { Triportheus } \\
\text { magdalenae }\end{array}$ & $\begin{array}{l}\text { LBP1899 } \\
\quad 3\end{array}$ & 75308 & $\begin{array}{c}\text { Rio Coelho/Rio } \\
\text { Magdalena/Coelho/Tolima/Colombia }\end{array}$ & $\begin{array}{l}\text { N } 04^{\circ} 17 ' 25.4^{\prime \prime} \mathrm{W} \\
74^{\circ} 53^{\prime} 28.1^{\prime \prime}\end{array}$ & $\begin{array}{c}\mathrm{KT} 28119 \\
0\end{array}$ & $\begin{array}{c}\mathrm{KT} 28121 \\
5\end{array}$ & $\begin{array}{c}\mathrm{KT} 28123 \\
7\end{array}$ & $\begin{array}{c}\mathrm{KT} 28126 \\
1\end{array}$ & $\begin{array}{c}\text { KT28128 } \\
4\end{array}$ \\
\hline $\begin{array}{l}\text { Triportheus } \\
\text { nematurus* }\end{array}$ & LBP39 & 3503 & Rio Miranda/Corumbá/MS/Brazil & $\begin{array}{l}\text { S } 19^{\circ} 34.630^{\prime} \\
\text { W } 57^{\circ} 01.123^{\prime}\end{array}$ & $\begin{array}{c}\text { HQ17138 } \\
3\end{array}$ & $\begin{array}{c}\text { HQ28967 } \\
0\end{array}$ & $\begin{array}{c}\text { HQ28909 } \\
1\end{array}$ & $\begin{array}{c}\text { HQ28928 } \\
4\end{array}$ & $\begin{array}{c}\text { HQ28947 } \\
6\end{array}$ \\
\hline $\begin{array}{l}\text { Triportheus } \\
\text { orinocensis* }\end{array}$ & LBP2663 & 15580 & $\begin{array}{c}\text { Laguna de Castilleros/Caicara del Orinoco } \\
\text { /Bolivar/Venezuela }\end{array}$ & $\begin{array}{l}\text { N } 07^{\circ} 30^{\prime} 50.9^{\prime \prime} \mathrm{W} \\
66^{\circ} 09^{\prime} 19.8^{\prime \prime}\end{array}$ & $\begin{array}{l}\text { HQ17125 } \\
3\end{array}$ & $\begin{array}{c}\text { HQ28954 } \\
4\end{array}$ & $\begin{array}{l}\text { HQ28896 } \\
3\end{array}$ & $\begin{array}{l}\text { HQ28916 } \\
0\end{array}$ & $\begin{array}{c}\text { HQ28935 } \\
1\end{array}$ \\
\hline $\begin{array}{l}\text { Triportheus } \\
\text { orinocensis }\end{array}$ & LBP9980 & 43125 & $\begin{array}{l}\text { Laguna de Castilleros/Caicara del Orinoco } \\
\text { /Bolivar/Venezuela }\end{array}$ & $\begin{array}{l}\text { N } 07^{\circ} 30^{\prime} 50.9^{\prime \prime} \mathrm{W} \\
66^{\circ} 09^{\prime} 19.8^{\prime \prime}\end{array}$ & $\begin{array}{c}\text { KT28118 } \\
1\end{array}$ & $\begin{array}{c}\mathrm{KT} 28121 \\
1\end{array}$ & $\begin{array}{c}\mathrm{KT} 28122 \\
3\end{array}$ & $\begin{array}{c}\mathrm{KT} 28125 \\
7\end{array}$ & $\begin{array}{c}\mathrm{KT} 28128 \\
1\end{array}$ \\
\hline $\begin{array}{l}\text { Triportheus } \\
\text { pantanensis }\end{array}$ & LBP8445 & 41694 & Lagoa Marginal/Rio Cuiabá/Cáceres/MT/Brazil & $\begin{array}{l}\text { S } 16^{\circ} 03^{\prime} 13.6^{\prime} \mathrm{W} \\
57^{\circ} 48^{\prime} 31.8^{\prime \prime}\end{array}$ & $\begin{array}{c}\text { KT28117 } \\
9\end{array}$ & $\begin{array}{c}\text { KT28120 } \\
0\end{array}$ & $\begin{array}{c}\text { KT28122 } \\
8\end{array}$ & $\begin{array}{c}\text { KT28124 } \\
6\end{array}$ & $\begin{array}{c}\text { KT28126 } \\
9\end{array}$ \\
\hline $\begin{array}{l}\text { Triportheus } \\
\text { pantanensis }\end{array}$ & LBP9251 & 44492 & Rio Paraguay/Cáceres/MT/Brazil & $\begin{array}{l}\text { S } 16^{\circ} 05^{\prime} 14.8^{\prime \prime} \mathrm{W} \\
57^{\circ} 42^{\prime} 17.8^{\prime \prime}\end{array}$ & $\begin{array}{c}\text { KT2 } 8118 \\
4\end{array}$ & $\begin{array}{c}\text { KT2 } 28120 \\
2\end{array}$ & $\begin{array}{c}\text { KT28122 } \\
9\end{array}$ & $\begin{array}{c}\text { KT28124 } \\
8\end{array}$ & $\begin{array}{c}\text { KT28127 } \\
1\end{array}$ \\
\hline $\begin{array}{l}\text { Triportheus } \\
\text { rotundatus }\end{array}$ & LBP2840 & 17042 & Lago do Silência/Boca do Acre/AM/Brazil & $\begin{array}{l}\text { S } 08^{\circ} 51^{\prime} 21.5^{\prime \prime} \mathrm{W} \\
68^{\circ} 42^{\prime} 22.6^{\prime \prime}\end{array}$ & $\begin{array}{c}\text { KT28117 } \\
1\end{array}$ & $\begin{array}{c}\text { KT28119 } \\
9\end{array}$ & $\begin{array}{c}\text { KT28121 } \\
9\end{array}$ & $\begin{array}{c}\text { KT28124 } \\
5\end{array}$ & $\begin{array}{c}\text { KT28126 } \\
8\end{array}$ \\
\hline $\begin{array}{l}\text { Triportheus } \\
\text { aff. } \\
\text { rotundatus }\end{array}$ & $\begin{array}{c}\text { LBP1191 } \\
7\end{array}$ & 45312 & Rio Miranda/Miranda/MS/Brazil & $\begin{array}{l}\text { S } 19^{\circ} 34^{\prime} 58.3^{\prime} \mathrm{W} \\
57^{\circ} 01^{\prime} 18.9^{\prime \prime}\end{array}$ & $\begin{array}{c}\text { KT28118 } \\
5\end{array}$ & $\begin{array}{c}\mathrm{KT} 28120 \\
1\end{array}$ & $\begin{array}{c}\text { KT28123 } \\
1\end{array}$ & $\begin{array}{c}\text { KT28124 } \\
7\end{array}$ & $\begin{array}{c}\text { KT28127 } \\
0\end{array}$ \\
\hline $\begin{array}{l}\text { Triportheus } \\
\text { signatus }\end{array}$ & LBP5534 & 27202 & Rio Balsas/Balsas/MA/Brazil & $\begin{array}{l}\text { S } 07^{\circ} 32^{\prime} 26^{\prime} \\
\text { W } 46^{\circ} 02^{\prime} 21^{\prime}\end{array}$ & $\begin{array}{c}\text { KT28117 } \\
6\end{array}$ & $\begin{array}{c}\text { KT } 28120 \\
9\end{array}$ & $\begin{array}{c}\text { KT28122 } \\
2\end{array}$ & $\begin{array}{c}\text { KT } 28125 \\
5\end{array}$ & $\begin{array}{c}\text { KT28127 } \\
9\end{array}$ \\
\hline $\begin{array}{l}\text { Triportheus } \\
\text { signatus }\end{array}$ & LBP6554 & 31049 & Rio Piracicaba/Santa Maria da Serra/SP/Brazil & $\begin{array}{l}\text { S } 22^{\circ} 38^{\prime} 23.1^{\prime \prime} \mathrm{W} \\
48^{\circ} 03^{\prime} 11.0^{\prime \prime}\end{array}$ & $\begin{array}{c}\text { KT28117 } \\
8\end{array}$ & $\begin{array}{c}\text { KT28121 } \\
0\end{array}$ & $\begin{array}{c}\text { KT28123 } \\
0\end{array}$ & $\begin{array}{c}\text { KT28125 } \\
6\end{array}$ & $\begin{array}{c}\text { KT28128 } \\
0\end{array}$ \\
\hline $\begin{array}{l}\text { Triportheus } \\
\text { trifurcatus }\end{array}$ & LBP5750 & 28111 & Rio Araguaia/Aragarças/GO/Brazil & $\begin{array}{l}\mathrm{S} 15^{\circ} 53^{\prime} 31.5^{\prime \prime} \mathrm{W} \\
52^{\circ} 15^{\prime} 02.0^{\prime \prime}\end{array}$ & $\begin{array}{c}\text { KT2 } 2117 \\
7\end{array}$ & $\begin{array}{c}\text { KT28120 } \\
8\end{array}$ & $\begin{array}{c}\text { KT28123 } \\
4\end{array}$ & $\begin{array}{c}\text { KT2 } 28125 \\
4\end{array}$ & $\begin{array}{c}\text { KT28127 } \\
8\end{array}$ \\
\hline $\begin{array}{l}\text { Triportheus } \\
\text { trifurcatus }\end{array}$ & LBP8775 & 44058 & $\begin{array}{c}\text { Lagoa do Chico/Rio } \\
\text { Araguaia/Cocalinho/MT/Brazil }\end{array}$ & $\begin{array}{l}\text { S } 13^{\circ} 19^{\prime} 22.8^{\prime} \mathrm{W} \\
50^{\circ} 37^{\prime} 20.7^{\prime \prime}\end{array}$ & $\begin{array}{c}\text { KT28119 } \\
1\end{array}$ & $\begin{array}{c}\text { KT28119 } \\
4\end{array}$ & $\begin{array}{c}\mathrm{KT} 28121 \\
8\end{array}$ & $\begin{array}{c}\text { KT28124 } \\
0\end{array}$ & - \\
\hline $\begin{array}{l}\text { Triportheus } \\
\text { venezuelensis }\end{array}$ & LBP2194 & 15523 & $\begin{array}{l}\text { Laguna de Castilleros/Caicara del Orinoco } \\
\text { /Bolivar/Venezuela }\end{array}$ & $\begin{array}{l}\text { N } 07^{\circ} 30^{\prime} 50.9^{\prime \prime} \mathrm{W} \\
66^{\circ} 09^{\prime} 19.8^{\prime \prime}\end{array}$ & $\begin{array}{c}\text { KT2 } 28117 \\
0\end{array}$ & $\begin{array}{c}\text { KT28120 } \\
5\end{array}$ & $\begin{array}{c}\mathrm{KT} 28123 \\
6\end{array}$ & $\begin{array}{c}\mathrm{KT} 28125 \\
1\end{array}$ & $\begin{array}{c}\text { KT28127 } \\
4\end{array}$ \\
\hline $\begin{array}{l}\text { Triportheus } \\
\text { venezuelensis }\end{array}$ & $\begin{array}{l}\text { LBP1191 } \\
\quad 8\end{array}$ & 19155 & $\begin{array}{l}\text { Rio Orinoco/Caicara del } \\
\text { Orinoco/Bolivar/Venezuela }\end{array}$ & $\begin{array}{l}\text { N } 07^{\circ} 38^{\prime} 11.6^{\prime \prime} \mathrm{W} \\
66^{\circ} 19^{\prime} 04.2^{\prime \prime}\end{array}$ & $\begin{array}{c}\text { KT28117 } \\
2\end{array}$ & $\begin{array}{c}\mathrm{KT} 28121 \\
3\end{array}$ & 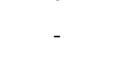 & $\begin{array}{c}\text { KT28125 } \\
9\end{array}$ & $\begin{array}{c}\text { KT28128 } \\
3\end{array}$ \\
\hline $\begin{array}{l}\text { Triportheus } \\
\text { sp. nov. }\end{array}$ & $\begin{array}{c}\text { LBP1593 } \\
0\end{array}$ & 63501 & Lagoa Margina/Rio Xingu/Canarana/MT/Brazil & $\begin{array}{l}\mathrm{S} 13^{\circ} 31^{\prime} 02.8^{\prime \prime} \mathrm{W} \\
53^{\circ} 04^{\prime} 41.8^{\prime \prime}\end{array}$ & $\begin{array}{c}\mathrm{KT} 28118 \\
9\end{array}$ & $\begin{array}{c}\text { KT28119 } \\
7 \\
\end{array}$ & $\begin{array}{c}\text { KT28123 } \\
5 \\
\end{array}$ & $\begin{array}{c}\mathrm{KT} 28124 \\
3 \\
\end{array}$ & $\begin{array}{c}\text { KT28126 } \\
6 \\
\end{array}$ \\
\hline
\end{tabular}


Table 2 Information content and characteristics of each molecular data partition. The upper line represents the values of Matrix 1 (total dataset), and the lower line represents the values of Matrix 2 (Triportheidae + Bryconidae + Gasteropelecidae + select Characidae).

\begin{tabular}{|c|c|c|c|c|c|c|}
\hline & & & Gene & & & \\
\hline & $16 \mathrm{~S}$ & CytB & Myh6 & Rag1 & Rag2 & Total \\
\hline \multirow[t]{2}{*}{ Number of sequences } & $294(100 \%)$ & $269(91.5 \%)$ & $245(83.3 \%)$ & $238(80.9 \%)$ & $257(87.4 \%)$ & 294 \\
\hline & $101(100 \%)$ & $96(95.0 \%)$ & $86(85.1 \%)$ & $81(80.2 \%)$ & $95(93.1 \%)$ & 101 \\
\hline \multirow[t]{2}{*}{ bp after alignment } & 653 & 992 & 755 & 1265 & 1034 & 4699 \\
\hline & 626 & 992 & 752 & 1265 & 1031 & 4666 \\
\hline \multirow[t]{2}{*}{ Number of variable sites } & 409 & 693 & 397 & 896 & 706 & 3101 \\
\hline & 314 & 593 & 282 & 617 & 461 & 2267 \\
\hline \multirow{2}{*}{$\begin{array}{l}\text { Number of informative } \\
\text { characters under parsimony }\end{array}$} & 333 & 589 & 330 & 701 & 592 & 2545 \\
\hline & 242 & 513 & 221 & 407 & 325 & 1708 \\
\hline \multirow{2}{*}{$\begin{array}{c}\% \text { informative characters } \\
\text { under parsimony }\end{array}$} & 50.9 & 59.3 & 43.7 & 55.4 & 56.2 & 54.2 \\
\hline & 38.7 & 51.7 & 29.4 & 32.2 & 31.5 & 36.6 \\
\hline \multirow[t]{2}{*}{$\Pi_{\mathrm{T}}$} & 0.226 & 0.297 & 0.247 & 0.226 & 0.232 & 0.246 \\
\hline & 0.225 & 0,295 & 0.246 & 0.226 & 0.232 & 0.246 \\
\hline \multirow[t]{2}{*}{$\Pi_{\mathrm{C}}$} & 0.236 & 0.291 & 0.213 & 0.240 & 0.251 & 0.249 \\
\hline & 0.235 & 0.286 & 0.213 & 0.242 & 0.252 & 0.249 \\
\hline \multirow[t]{2}{*}{$\Pi_{\mathrm{A}}$} & 0.314 & 0.266 & 0.307 & 0.253 & 0.245 & 0.271 \\
\hline & 0.315 & 0.270 & 0.306 & 0.257 & 0.244 & 0.273 \\
\hline \multirow[t]{2}{*}{$\Pi_{\mathrm{G}}$} & 0.224 & 0.146 & 0.234 & 0.281 & 0.272 & 0.234 \\
\hline & 0.225 & 0.149 & 0.234 & 0.276 & 0.271 & 0.233 \\
\hline \multirow{2}{*}{$\begin{array}{c}\text { Overall mean genetic } \\
\text { distance } \\
\text { (p-distance) }\end{array}$} & $0.124 \pm 0.007$ & $0.215 \pm 0.007$ & $0.083 \pm 0.005$ & $0.108 \pm 0.004$ & $0.107 \pm 0.004$ & $0.135 \pm 0.003$ \\
\hline & $0.108 \pm 0.007$ & $0.209 \pm 0.007$ & $0.062 \pm 0.005$ & $0.075 \pm 0.004$ & $0.069 \pm 0.004$ & $0.112 \pm 0.003$ \\
\hline \multirow{2}{*}{$\begin{array}{l}\text { Nucleotide substitution } \\
\text { model }\end{array}$} & $\mathrm{GTR}+\mathrm{I}+\Gamma$ & $\mathrm{GTR}+\mathrm{I}+\Gamma$ & $\mathrm{T} 92+\mathrm{I}+\Gamma$ & $\mathrm{K} 2 \mathrm{P}+\mathrm{I}+\Gamma$ & $\mathrm{K} 2 \mathrm{P}+\mathrm{I}+\Gamma$ & $\mathrm{GTR}+\mathrm{I}+\Gamma$ \\
\hline & $\mathrm{GTR}+\mathrm{I}+\Gamma$ & $\mathrm{GTR}+\mathrm{I}+\Gamma$ & Т92+Г & Т92+Г & $\mathrm{K} 2 \mathrm{P}+\Gamma$ & $\mathrm{GTR}+\mathrm{I}+\Gamma$ \\
\hline \multirow{2}{*}{$\begin{array}{c}\alpha \text { (shape) parameter of } \Gamma \\
\text { distribution }\end{array}$} & 0.58 & 0.65 & 1.03 & 0.88 & 0.92 & 0.63 \\
\hline & 0.63 & 1.09 & 0.33 & 0.33 & 0.48 & 0.56 \\
\hline \multirow{2}{*}{$\begin{array}{l}\text { Proportion of invariants (I) } \\
\text { sites } \\
\end{array}$} & 0.27 & 0.29 & 0.42 & 0.21 & 0.23 & 0.28 \\
\hline & 0.29 & 0.36 & - & - & - & 0.29 \\
\hline
\end{tabular}


Table 3 Comparison of log likelihoods and AIC and BIC values among different partitioning schemes (from 1 to 13 partitions) for Matrix 1 (all data) and Matrix 2 (Triportheidae + Bryconidae + Gasteropelecidae + selected Characidae). For each type of analysis, the following results are shown: total number of parameters, log likelihood calculated using RAxML $\left(L_{M L}\right)$, AIC values, the difference in AIC values among model $\mathrm{i}$ and the best model $(\Delta i=\mathrm{AIC} i-\mathrm{AICmin})$, and $\mathrm{BIC}_{M L}$ values.

\begin{tabular}{|c|c|c|c|c|c|}
\hline $\begin{array}{c}\text { Number of } \\
\text { partitions* } \\
\text { Matrix 1 }\end{array}$ & $\begin{array}{c}\text { Number of } \\
\text { parameters }\end{array}$ & $\mathrm{L}_{M L}$ & $\mathrm{AIC}$ & Delta $_{i}$ & BIC $_{M L}$ \\
\hline 1 & 9 & 196068,217 & 392154,434 & 10095,659 & 392169,482 \\
\hline 2 & 19 & 195317,812 & 390673,625 & 8614,850 & 390705,393 \\
\hline 4A & 39 & 195525,437 & 391128,874 & 9070,099 & 391194,082 \\
\hline 4B & 39 & 195264,504 & 390607,008 & 8548,233 & 390672,216 \\
\hline 5 & 49 & 195152,445 & 390402,891 & 8344,116 & 390484,819 \\
\hline 13 & 129 & 190900,388 & 382058,775 & 0,000 & 382274,464 \\
\hline Matrix 2 & & & & & \\
\hline 1 & 9 & 56036,502 & 112091,005 & 1750,540 & 112106,053 \\
\hline 2 & 19 & 55884,183 & 111806,366 & 1465,901 & 111838,134 \\
\hline 4A & 39 & 55932,866 & 111943,731 & 1603,267 & 112008,939 \\
\hline 4B & 39 & 55854,879 & 111787,759 & 1447,294 & 111852,967 \\
\hline 5 & 49 & 55753,934 & 111605,869 & 1265,405 & 111687,797 \\
\hline 13 & 129 & 55041,232 & 110340,464 & 0,000 & 110556,153 \\
\hline
\end{tabular}

$* 1$ partition $=$ whole dataset; 2 partitions $=$ mitochondrial $(16 \mathrm{~S}+\mathrm{CytB})$ and nuclear $($ Myh6 + Rag1 + Rag2); 4 partitions A = 16S and 1st, 2nd, and 3rd codon position of protein coding genes; 4 partitions $\mathrm{B}=16 \mathrm{~S}+\mathrm{CytB}$ and 1st, 2nd, and 3rd codon position of nuclear genes; 5 partitions = by each gene $(16 \mathrm{~S}+\mathrm{CytB}+$ Myh6 + Rag1 + Rag2); 13 partitions $=16 \mathrm{~S}+$ each codon position of each protein coding gene (1st, 2nd, and 3rd codon position of CytB; 1st, 2nd, and 3rd codon position of Myh6; 1st, 2nd, and 3rd codon position of Rag1; 1st, 2nd, and 3rd codon position of Rag2). 